\title{
Os Desafios que os Modernos Areópagos apresentam para a Evangelização segundo a Encíclica "Redemptoris Missio" do Papa João Paulo II
}

Maria Clara Lucchetti Bingemer

Na Encíclica Redemptoris Missio, o Papa João Paulo II identifica alguns desafios prioritários à missão evangelizadora da Igreja que surgem a partir do que ele chama de "modernos areópagos". Assim, o Papa introduz a questão:

Áreas culturais, ou modernos areópagos. Paulo, depois de ter pregado em numerosos lugares, chega a Atenas e vai ao areópago, onde anuncia o Evangelho, usando uma linguagem adaptada e compreensível para aquele ambiente (cf. At 17,22-31). O areópago representava, então, o centro da cultura do douto povo ateniense, e hoje pode ser tomado como símbolo dos novos ambientes onde o Evangelho deve ser proclamado.

A expressão areópagos remete diretamente a outra expressão: a missão "ad gentes". Esta refere-se, primeiramente, aos grupos humanos que ainda não têm uma explícita adesão à pessoa de Jesus Cristo e não o reconhecem como salvador. A história do termo está revestida de uma longa tradição: surgiu no seio das primeiras comunidades cristãs e assumiu, historicamente, conotações, às vezes, negativas. Por muito tempo, a abertura missionária "ad

\footnotetext{
${ }^{1}$ Comunicação apresentada no painel comemorativo da beatificação do Papa João Paulo II. O painel teve lugar na PUC-Rio, em 25 de abril de 2011.
} 
gentes" foi revestida de uma roupagem de conquista espiritual. Hoje, o termo não tem significados valorativos, mas exprime somente a realidade de um grande número de pessoas que não tem Jesus Cristo como referência.

João Paulo II deixa entrever no texto de sua encíclica a preocupação para que estes areópagos e as "gentes" que os habitam possam ser alcançados de alguma maneira pela Boa Nova do Evangelho.

Seria impossível comentar aqui, no pouco tempo de que dispomos, todos os desafios que João Paulo II infere da identificação que faz dos modernos areópagos. Destacaremos três que nos parecem especialmente importantes para nós, aqui nesta Universidade Católica, a PUC-Rio.

1) O primeiro seria a pastoral urbana. Há muitos âmbitos em que se desenvolve a missão "ad gentes". Um âmbito particularmente emergente é representado pelas grandes cidades e pelas megalópoles. Nos dias de hoje, a cidade e o seu mundo estão se tornando cada vez mais uma realidade missionária "ad gentes”. João Paulo II em sua encíclica missionária, Redemptoris Missio, fala de uma realidade urbana e de "novos areópagos" como campos missionários emergentes. Com mais ênfase, o desafio prioritário da missão é constituído, hoje, pelo mundo das grandes megalópoles. É verdade que, desde os primeiros tempos da Igreja, os cristãos tinham-se espalhados pelas cidades da Grécia, do Império Romano e da Ásia. Sucessivamente, porém, a missão "ad gentes" privilegiou as áreas rurais e as periferias do mundo. Hoje, após o grande êxodo rural, o mundo tornou-se urbanizado e uma grande onda de migrantes, que, muitas vezes, forçosamente, se deslocaram para os grandes aglomerados urbanos.

A missão defronta-se, portanto, com esta nova realidade. Os missionários, acompanhando o fluxo das pessoas, estão sempre mais se deslocando para as áreas urbanas.

Muitas perguntas surgem a partir desta mudança. Antes de tudo, a missão tradicional deve ser revista e atualizada. Novos desafios e questões colocam em cheque a maneira tradicional de evangelizar. Há uma necessidade de entender como se processa o estilo de vida da cidade e seu dinamismo cultural. A fragmentação e o pluralismo questionam uma única maneira de ser missionário. Em vez de repetir o que se sabe, há o convite a recriar constantemente os caminhos. As fronteiras, abrindo-se, tornam-se mais complexas. Tradicionalmente, trabalhava-se no meio de grupos homogêneos e as visitas esporádicas eram suficientes para sustentar uma cosmovisão cristã. Hoje, não é mais assim. O que vem a ser a "missão urbana"? Quais experiências estão sendo implementadas e quais métodos de fazer missão estão surgindo? 
2) O segundo seria a universidade como espaço pluralista de gestação da cultura. "É preciso lembrar, além disso, o vastíssimo areópago da cultura, da pesquisa científica, das relações internacionais que favorecem o diálogo e levam a novos projetos de vida. Convém estar atentos e empenhados nestas exigências modernas. Os homens sentem-se como que a navegar no mesmo mar tempestuoso da vida, chamados a uma unidade e solidariedade cada vez maior: as soluções para os problemas existenciais são estudadas, discutidas e experimentadas com o concurso de todos. Eis porque os organismos e as convenções internacionais se apresentam cada vez mais importantes, em muitos sectores da vida humana, desde a cultura à política, da economia à pesquisa Os cristãos, que vivem e trabalham nesta dimensão internacional, tenham sempre presente o seu dever de testemunhar o Evangelho.

3) O terceiro seria a imensa sede espiritual que brota por todos os lados em meio á secularidade desencantada e refratária a muitas formas religiosas institucionais. "A época em que vivemos é, ao mesmo tempo, dramática e fascinante. Se por um lado, parece que os homens vão ao encalço da prosperidade material, mergulhando cada vez mais no consumismo materialista, por outro lado, manifesta-se a angustiante procura de sentido, a necessidade de vida interior, o desejo de aprender novas formas e meios de concentração e de oração. Não só nas culturas densas de religiosidade, mas também nas sociedades secularizadas, procura-se a dimensão espiritual da vida como antídoto à desumanização. Este fenômeno, denominado « ressurgimento religioso », não está isento de ambigüidade, mas traz com ele também um convite. A Igreja tem em Cristo, que se proclamou «o Caminho, a Verdade e a Vida » $\left(J_{o} 14,6\right)$, um imenso patrimônio espiritual para oferecer à humanidade. É o caminho cristão que leva ao encontro de Deus, à oração, à ascese, à descoberta do sentido da vida. Também este é um areópago a evangelizar."

Diante de todos estes desafios surgidos a partir dos modernos areópagos, no entanto, importa reconhecer que João Paulo II não privilegia nem reforça em nenhum momento uma visão impositiva da evangelização e da missão. Pelo contrário, repete incessantemente a importância da liberdade humana e do "sacrário da consciência" que devem ser respeitados a todo custo.

No n. 39 da encíclica, diz: "Por outro lado, a Igreja dirige-se ao homem no pleno respeito da sua liberdade: a missão não restringe a liberdade, pelo contrário, favorece-a. A Igreja propõe, não impõe nada: respeita as pessoas e as culturas, detendo-se diante do sacrário da consciência Aos que se opõem 
com os mais diversos pretextos à atividade missionária, a Igreja repete: Abri as portas a Cristo!"

Parece-nos que esta postura do Pontífice tem muito a nos dizer aqui e agora, neste espaço plural e livre que é e quer ser a Universidade. Para nós que aqui estamos e que vivemos a fé cristã, o desafio é saber manter esta sadia tensão entre o respeito e a missão. Não desejar impor nada, mas não poder deixar de propor aquilo que é o segredo de nossa esperança e alegria parece-me ser a mensagem que João Paulo II nos deixa e que vale a pena recordar estando próximos a este acontecimento eclesial de sua beatificação.

Maria Clara Lucchetti Bingemer

Professora de Teologia Sistemática na PUC-Rio Doutora pela Pontifícia Universidade Gregoriana de Roma

Comunicação Recebida em 1\%08/2011 Comunicação Aprovada em 02/08/2011 